\title{
Pushback on drug ads
}

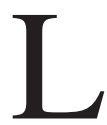

ike most physicians in the United States, Dr. Ryan Gray has seen his share of prescription drug ads on television. Many are cringeworthy, he says, citing as an example the one he saw recently for a drug to treat opioid-induced constipation.

"This is an example of a drug company creating a disease because they have a medication they can sell for it," says Gray, a former flight surgeon for the United States Air Force who runs the online resource Medical School Headquarters.

His frustration with pharmaceutical advertising prompted him to write an article called "Get Big Pharma Off of My TV Screen and Out of My House." According to Gray, US television viewers are bombarded with messages that lead many to believe they are suffering from health problems they don't actually have. They then visit their doctors and demand the brand-name drugs they saw in ads. And if a doctor doesn't comply — well, there is always another doctor.

"The presence of ads is getting in the way of the doctor-patient relationship," says Gray.

The only other country that permits direct-to-consumer advertising of prescription medication is New Zealand. But could that change? Will the US someday leave New Zealand to stand alone by joining the rest of the word in banning consumer drug ads? That would indeed be the case if the American Medical Association (AMA) had its way.

On Nov. 17, 2015, the AMA called for a ban on direct-to-consumer advertising of prescription drugs and medical devices. According to the association's statement, the billions of dollars spent on marketing by pharmaceutical companies fuels "escalating drug prices" and "inflates demand for new and more expensive drugs, even when these drugs may not be appropriate."

In response to a request for an update on this issue, an AMA media representative wrote in an email that a "strategy to advance the new AMA policy in support of a consumer ad ban on prescription drugs and devices is under development at the AMA" and said no new information is available.

It is somewhat surprising that it took this long for the AMA to take a stand against consumer drug ads, says Barbara Mintzes, senior lecturer in the pharmacy faculty at the University of Sydney. The Canadian Medical Association, after all, approved a policy opposing such ads more than 13 years ago.

Considering the success of drug ads in the US, the pharmaceutical industry has attempted to gain permission to advertise to consumers in Canada, Australia and other countries with bans, says Mintzes. So far, none have succeeded. An attempt to allow direct-to-consumer advertising of drugs in the European Union, for example, was voted down 494-42 by European Parliament in 2002.

Getting drug ads off American broadcasts and out of online and print publications won't be easy. For one, the pharmaceutical industry has a huge lobbying presence in the US. In fact, it tops the list, according to OpenSecrets. org, with $\$ 3.2$ billion spent on lobbying since 1998. That's a billion more than the next-biggest spender, the insurance industry. Another reason, says Mintzes, is that the US has "a very strong legal protection of commercial freedom of expression."

Still, anything is possible, and the AMA is an influential organization. "It certainly has both money and clout," says Mintzes. "The question is: will they take this policy statement forward and actually have a strategy for how they would work toward implementation."

But even if the AMA does increase the pressure to ban consumer drugs ads in the US, it's not likely to happen, according to Dan Jaffe, group executive vice president of government relations for the Association of National Advertisers. "Under our laws, restrictions on speech must be a last resort, not a first resort," says Jaffe.

Besides, he suggests, if consumers can't learn about new drugs from pharmaceutical ads, they will simply turn to the Internet, and that information may be inaccurate. The US Food and Drug Administration (FDA) has strong powers to control the content of drugs ads, he notes, so the information they contain can be trusted.

"Of all the categories of advertising, prescription drugs are one of, if not the most, heavily regulated," says Jaffe. "The odds of false or deceptive advertising are low."

As for arguments that consumer drug ads lead to unnecessary use of drugs and drive demand for high-priced medications, Jaffe isn't buying it. Unlike other consumer goods, such as televisions or vehicles, prescription drugs can only be obtained with the consent of a physician.

"You have a highly trained intermediary," he says. "To make that argument, you have to believe that doctors are incapable of talking to their patients and saying "no" or telling them there is a less expensive alternative." - Roger Collier, CMAJ

CMAJ 2016. DOI:10.1503/cmaj.109-5223 